\title{
China e Índia - emergência e impacto cultural
}

\author{
The rise of China and India - the cultural impact
}

PAULO ANTÔNIO PEREIRA PINTO*

Rev. Bras. Polit. Int. 50 (1): 86-101 [2007]

\section{Introdução}

China e Índia ocupam atualmente parcelas quase idênticas de interesse no noticiário internacional. Os chineses já despertavam atenções, desde o início do processo de abertura da República Popular ao exterior, na década de 1980. Os indianos, mais recentemente, passaram a provocar enorme curiosidade, pela ruptura gradual em curso com modelo de desenvolvimento tradicionalmente fechado, em descompasso com a globalização.

Este artigo visa a uma reflexão sobre aspectos políticos de dois momentos definitivos na evolução política contemporânea daqueles dois países, verdadeiras novas cenas de partida na história recente do continente asiático: o início da década de 1980, quando a China iniciou seu processo de abertura para o exterior; e os dias de hoje, quando as atençōes mundiais se voltam para o "fenômeno" do crescimento acelerado chinês e indiano.

O exercício se deve ao fato de que a emergência atual das nações mais populosas do planeta é, com freqüência, analisada apenas na perspectiva da crescente inserção internacional de suas economias, bem como a partir da cobiça quanto ao acesso de centenas de milhões de seus potenciais consumidores à oferta de produtos e serviços estrangeiros. Tais avaliações estariam mais adequadas ao debate, nas últimas décadas do século XX, quando o processo de globalização começou a prevalecer sobre as economias fechadas e centralmente planificadas.

Assim, o foco prioritário na dimensão econômica, até o final do século passado, levava a crer que o progresso tecnológico em comunicaçôes promoveria maior cooperação e entendimento entre os povos. Com um maior acesso à informação, os eleitores se tornar-se-iam mais independentes e racionais. $\mathrm{Na}$ medida em que as sociedades se tornassem mais afluentes, acreditava-se, superariam paixões "tribais" ou nacionalismos extremados, enquanto instituições globalizadas se consolidariam, criando, mesmo, um novo ordenamento internacional.

\footnotetext{
* Diplomata brasileiro, atualmente servindo como Cônsul-Geral do Brasil em Mumbai, Índia. As opiniōes expressas no artigo são de sua exclusiva responsabilidade e não refletem posições do Ministério das Relações Exteriores (papinto2006@gmail.com).
} 
Parece, contudo, ter acontecido o contrário, pois, enquanto o mundo tornouse mais rico e melhor informado, as crenças religiosas também se fortaleceram. Nacionalismo e tribalismo tampouco desapareceram ${ }^{1}$. Na prática, instituiçōes transnacionais, como a ONU e a União Européia tornaram-se fracas e sujeitas a crises.

Sabemos, agora, que a criação de uma economia global e a emergência de novas forças tecnológicas não erodiram culturas e valores locais. Verificou-se, pelo contrário, que, na medida em que as pessoas tiveram acesso a maior informação e educação, suas diferenças culturais se tornaram mais pronunciadas - não menos. Nesse processo, diferentes grupos demonstraram perseguir visões distintas de bem-estar, assim como reagiram de formas agressivas a ameaças perceptíveis a sua dignidade cultural ${ }^{2}$. As pessoas, agora, aparecem menos como indivíduos egoístas, voltados para a satisfação material, e mais como seres inseridos em suas respectivas sociedades.

O estudo da emergência atual da China e Índia, deveria levar em conta, portanto, que o grande desafio do século atual é o entendimento de como as culturas evoluem, adaptam-se ou permanecem estáveis. O foco prioritário deste estudo, portanto, visa a mapear tendências que possam resultar destas alterações no cenário internacional.

Nesse sentido, chamam atenção especial, por um lado, as declarações da China, em 2005, de que sua condição atual de potência emergente deve ser entendida como uma nova fase histórica, marcada por "ascensão pacífica" do país, destinada a beneficiar seu entorno imediato e relações com o exterior ${ }^{3}$. Segundo este discurso chinês, estaria em curso, praticamente, o ressurgimento da influência político-cultural que o antigo Império do Centro exercia sobre as nações situadas ao Sul de suas fronteiras. Isto é, historicamente - sempre de acordo com Pequim - laços foram mantidos com o Sudeste Asiático, com base em relacionamento "pacífico", que a RPC, agora, procuraria "reacender"4.

Por outro, a Índia não busca nem expandir sua cultura, nem suas instituições democráticas. O que os indianos parecem analisar com grande precisão são os quesitos necessários para a preservação da segurança de sua multiculturalidade, no contexto de entorno imediato pacífico ${ }^{5}$. A liderança atual indiana, portanto, parece entender que a inquietação mundial, provocada por rivalidades étnicas e religiosas,

1 RAO, Vijayendra e WALTON, Michael. "Culture and Public Action”. Stanford: Stanford Social Sciences, Stanford University Press, 2004, p. 3.

2 Harrison, Lawrence E. \& Huntington, Samuel P. (Eds.). Culture Matters: How Values Shape Human Progress. New York: Basic Books, 2000, p. 2-65.

3 PEREIRA PINTO, Paulo Antônio. "China - a ascensão pacífica na Ásia Oriental". Revista Brasileira de Politica Internacional, Vol. 48, No. 2, 2005, p.70-85.

4 PEREIRA PINTO, Paulo Antônio. A China e o Sudeste Asiático. Porto Alegre: Editora da Universidade Federal do Rio Grande do Sul, 2000, p. 15.

5 KISSINGER, Henry A. "India and America - Anatomy of a partnership". International Herald Tribune, 11.3.2006. 
poderá afetar, também, a estabilidade de seu próprio país. Daí, Nova Delhi ter que exercer amplo leque de interlocução com culturas que rodeiam a Índia ${ }^{6}$.

\section{As origens das duas civilizações}

Verifica-se, a propósito, que se por um lado existem no Oriente e Ocidente características sociais comuns a toda a humanidade, por outro, China e Índia foram historicamente influenciadas por formas específicas de organização, determinadas pelo clima e relevo regionais, e pelo conjunto de crenças e valores que levaram a diferentes instituições políticas e ideologias. Esta primeira parte tratará de condicionantes geográficas, que contribuíram para moldar as civilizações daqueles dois países, que, apesar de distintas, compartilham, no entanto, de efeitos de uma natureza ao mesmo tempo rica e invasora.

O clima, nessa perspectiva, permite distinguir claramente as regióes geográficas que formam a Ásia. Ao Norte, se estende a Ásia continental, isto é a Sibéria; ao Centro, aparecem desertos imensos; no Oeste, o clima mediterrâneo predomina, com algumas variações - todos estes tipos climáticos encontram equivalentes em outras partes do mundo. No Subcontinente Indiano, contudo, há um fenômeno original, sem réplica alhures. Trata-se das monções, que ocorrem, em geral, de abril a setembro, e se caracterizam por fortes chuvas, que, por um lado, ajudam a desenvolver a agricultura e, por outro, podem causar inundaçóes, colocando em risco a vida humana.

A vida, naquela região está ligada às variações deste clima das monções, que provoca ventos dos oceanos em direção ao continente, no verão, e do continente em direção aos oceanos, no inverno. O relevo também influenciou a ocupação humana, na medida em que reduziu as opções de áreas habitáveis ${ }^{7}$.

A ocupação humana organizada na Ásia ocorreu, na China, a partir do terceiro milênio antes de Cristo. A civilização chinesa desenvolveu-se nas grandes planícies do Norte, onde a terra é amarela, chamada de loess, e favorece a agricultura. A Índia foi povoada cerca de mil anos depois, com o surgimento de cidades com estruturas básicas. A grande pluviosidade foi, sem dúvida, o motivo que atraiu sucessivas levas de novos habitantes.

A Ásia das monções apresenta uma mistura complexa de civilizações de origens diversas, resultante de invasões sucessivas. Não se pode falar, nem no passado, nem hoje, em "unidade étnica", na medida em que "raças" diferentes dividiram esta região e a ocuparam, em diferentes áreas e períodos ${ }^{8}$.

Em função do relevo, a Índia permanece fechada à Ásia Central. A imensa barreira imposta pelo Himalaia separa solidamente a planície chinesa da bacia do

6 COHEN, Stephen Philip. Emerging Power India. Washington: Brookings Institution Press, 2001, p. 36. GIRARD, Luis. Collection d'Histoire: Le Monde Contemporain - Histoire - Civilizations. Bordas, 1966, p. 399. DOBBS-HIGGINSON, Michael S. Asia Pacific: A view on its role in the New World Order. Hong Kong: Longman Group-Far East, p. 167-199. 
rio Gange. Em contrapartida, a Índia se abre em direção ao Ocidente. Apesar de quase desértico, o planalto iraniano - vizinho ao subcontinente indiano - não é intransponível e, portanto, sucessivas levas de imigrantes chegaram à Índia, procedentes da Ásia Ocidental, atravessando a Pérsia?.

A Índia é, também, aberta ao exterior através do Golfo de Bengala, proporcionando-lhe uma vocação marítima e ligações comerciais milenares com diferentes partes do mundo.

Segundo dados disponíveis, os primeiros habitantes da Índia foram tribos "arianas" ou "indo-européias", originárias da Europa. Os "arianos" (Aryas) não modificaram as culturas encontradas no território que vieram ocupar. Introduziram, no entanto, o sistema de divisão da sociedade em "castas" estanques, que viria a alterar definitivamente as relações sociais em âmbito estrito e rígido ${ }^{10}$.

Por influência dessas novas levas migratórias, são fortalecidos os vínculos com a Indochina, sem que este sistema de castas seja exportado para aquela sub-região. Registra-se, contudo, que a "ação civilizadora" exercida no Sudeste Asiático ${ }^{11}$, a partir do ano Mil antes de Cristo é de origem indiana ${ }^{12}$.

Enquanto isso, a China - separada da Índia, ao Sul, pelo Himalaia - abrese para o Norte e Noroeste, interagindo com povos da Mongólia, Turquestão, planície Caspiana e Mar Negro. Os contatos dos chineses com o exterior são feitos por via terrestre. A China é, portanto, muito menos voltada para o mar, do que a Índia. Sua influência estende-se até o Japão, transitando pela península coreana. Atinge, também, parte da Indochina. $\mathrm{O}$ mundo chinês é, portanto, mais concentrado sobre si próprio, do que o indiano.

O povoamento destas regiões é muito antigo. As populações foram se adaptando às condições naturais, aprendendo a utilizar a terra com criatividade, tornando-se sociedades agrícolas. Apesar de diferenças notáveis, entre as culturas chinesa e indiana, a espiritualidade asiática é marcada pela submissão às forças da natureza, bem como pela busca de riqueza e desenvolvimento puramente interior dos indivíduos.

\section{A espiritualidade nas duas culturas}

A título de reflexão, procurar-se-á, a seguir, analisar, em linhas reconhecidamente simplificadas, a importância da dimensão cultural na emergência da China e Índia e suas diferentes percepções quanto à espiritualidade.

9 HOPKIRK, Peter. The Great Game - The Struggle for Empire in Central Asia. New York: Kodansha America, 1994, p. 38.

10 KEAY, John. India - A History. New York: Grove Press, 2000, p. 19-36.

11 DHORAISINGAM, Samuel S. Pernakan Indians of Singapore and Melaka. Cingapura: Institute of Southeast Asian Studies, 2006, p. 1-107.

12 DEVARE, Sudhir. India and Southeast Asia - Towards Security Convergence. Cingapura: Institute of Southeast Asian Studies, 2006, p. 160. 
Verifica-se, a propósito, que a mente ocidental judaico-cristã desenvolveu e favoreceu uma visão otimista da evolução da humanidade e, nesse processo, consolidou-se uma fé na capacidade de o homem aperfeiçoar-se, através de um melhor planejamento, da tecnologia, da ampliação da educação e da abertura de oportunidades para todos.

Enquanto isso, o pensamento asiático, hindu-budista, se sente à mercê de forças destrutivas, entre estas, a da natureza (como as doenças), a dos homens (como a guerra) e do passar do tempo, que, ao decorrer da longa história das nações daquela parte do mundo, tem engolido indivíduos, reinos e cidades.

No Ocidente, valoriza-se a genialidade humana para inventar, organizar e disciplinar o espaço geográfico, com o intuito de controlar as forças móveis da natureza. Assim, os indivíduos são os agentes que provocam mudanças - a natureza permanece a mesma. Esta pode ser conquistada pela análise científica e pode ser subjugada pelos avanços da humanidade.

Os pensadores europeus do Século XVIII acreditavam no "iluminismo coletivo", isto é, na sabedoria, como um combate à escuridão do desconhecimento, tornando a sociedade perfeita, nobre e pura. Os do Século XIX valorizaram o progresso material e coletivo, a conquista das forças da natureza, a abolição da violência, da escravidão, da injustiça e a vitória sobre o sofrimento e morte prematura. O Ocidente chegou, ao Século XX, ciente de que apenas com intenso e extenso planejamento e organização pode a civilização humana ser salva ${ }^{13}$.

No mundo ocidental, hoje, a fragilidade da vida humana não causa mais obsessão, na forma sofrida pelos antepassados, dos Séculos XV e XVI. Ao invés de atitude de aceitação, resignação e contemplação, cultiva-se uma vida de movimento constante, provocando mudanças a cada volta, melhorando e planejando as coisas, submetendo o crescimento do mundo a alterações previsíveis. Em suma, ao invés de procurar entender a vida e o cosmo como um todo, busca-se o controle sobre detalhes concretos.

Segundo estudiosos do assunto, a essência de qualquer sistema filosófico pode ser melhor entendida na forma condensada de seus termos principais. Uma exposição elementar, portanto, deve preocupar-se com a apresentação e interpretação das palavras através das quais as principais idéias devem ser formuladas. O pensamento indiano é muito bem adaptado a tal abordagem, pois todos os seus termos pertencem ao Sânscrito e servem há longo tempo à língua diária, à literatura e à medicina. Não são, portanto, termos confinados à atmosfera estranha e pouco familiar das escolas de pensamento ou doutrinas especializadas ${ }^{14}$.

Os substantivos, que constituiriam a maior parte da terminologia filosófica, são apresentados ao lado de verbos que derivam da mesma raiz e denotam atividades ou processos que expressam o mesmo contexto. Pode-se chegar ao significado

13 GIRARD, Luis. Op. Cit., p. 407.

14 ZIMMER, Heinrich, (edited by Joseph Campbel). Philosophies of India. Princeton: Princeton, 1989, p. 42. 
básico das palavras através do estudo de seu uso habitual na vida diária, assim entendendo tanto seus valores e variaçôes, quanto metáforas e conotaçōes. Tudo isso contrasta com a situação no Ocidente contemporâneo, onde a maior parte dos termos filosóficos foram emprestados do Grego ou Latim, situando-se, assim, destacados da vida real e, portanto, sofrendo de inevitável falta de vivacidade e claridade ${ }^{15}$.

A palavra "idéia", por exemplo, tem significado diferente para o momento histórico vivido por Platão ou David Locke, e ainda distinto para a história moderna das "idéias" ou Psicologia. No caso de cada autor ou escola de pensamento, esta palavra terá seu próprio significado. No vocabulário indiano, contudo, as palavras terão sempre a mesma interpretação e serão entendidas de forma igual, seja qual for o momento histórico. Por exemplo, a ênfase colocada no ideal supremo e final de "moksa", só pode ser entendido, no mundo ocidental, no contexto tradicional indiano e, não, no mundo moderno industrializado. Moksa é uma força inerente em cada traço, em cada aspecto e em cada disciplina da vida indiana e que molda toda a escala de valores daquela sociedade ${ }^{16}$.

A espiritualidade asiática foi sempre intensa, a ponto de permear a arte, tornando-a, com freqüência, expressão tipicamente religiosa.

$\mathrm{Na}$ China, durante períodos como o da Dinastia Tang (entre 618 e 907 DC) houve a construção de estátuas imensas e pagodes. Mas os chineses vivenciaram momentos em que floresceu uma arte desengajada de qualquer preocupação divina ${ }^{17}$.

A Índia, de sua parte, sempre esteve inteiramente voltada para a especulação religiosa. As primeiras grandes construções indianas datam do II milênio antes de Cristo e são santuários. Em seguida, vieram as "stupas", que são imensas construções "hemisféricas" ou cônicas, ao mesmo tempo, símbolos místicos e monumentos comemorativos.

Entre os séculos IX e XVIII D.C. a Índia se cobre de templos, enquanto a influência espiritual indiana se estende pelo Sudeste Asiático. Os imensos conjuntos de Angkor Vat, no Camboja, e os templos de Bangkok são alguns exemplos do papel espiritual desempenhado pela Índia.

A Ásia das monções, contudo, não foi berço de religião alguma - no sentido de ter fornecido um conjunto de regras, dogmas, revelaçõos religiosas precisas, acompanhadas de imperativos. A espiritualidade asiática, portanto, não segue ordenamento prático, nos moldes aos quais está acostumado o Ocidente. Tratase, antes de tudo, de um exercício de meditação, um voltar-se para o seu próprio interior, um esforço de concentração.

15 ZIMMER, Heinrich, (edited by Joseph Campbel). Myths and Symbols in Indian Art and Civilization. Princeton: Princeton University Press, 1974, p. 3-22.

16 ZIMMER, Heinrich. Philosophies of India. Op. cit., p. 47.

17 SHOUYI, Bai. An Outline History of China. Beijing: Foreign Languages Press, 1982, p. 174. 
Uma análise superficial da espiritualidade indiana parece indicar que esta se aproximaria de formas religiosas do Ocidente. À época das invasões indoeuropéias, a Índia assiste à implantação em seu território de uma tradição religiosa à qual é dado o nome de "Veda"(o Saber). O Veda é uma revelação "vinda do alto", mas não pode ser comparada às revelações na forma concebida pelas "religiōes mediterrâneas"18. O "Saber" seria proveniente do "Bhrama"que é, em grande medida, a "palavra", o "Espírito Absoluto". O Bhrama é a "unidade", cada alma é uma parte destacada deste unidade, que só se reencontra quando volta a se fundir no "todo".

Essa crença foi denominada Bramanismo ou Hinduísmo, com seus "deuses" maiores ou menores, seus templos e cerimoniais. Desenvolveu-se, assim, um ritual do Bramanismo, paralelamente a um aspecto puramente espiritual, que é a espera pelo retorno ao "Universal".

No século VI antes de Cristo, uma nova concepção espiritual, o Budismo, se expandiu a partir do Himalaia. Verifica-se, a propósito, que o Budismo não pretende, nem inovar, nem complementar, nem combater e nem substituir o Bramanismo. Desenvolveu-se ao lado do Bramanismo, sem confirmá-lo ou contradizê-lo.

O Budismo foi apresentado à Índia em momento de grande convulsões sociais, provocadas por guerras internas e invasões externas. Seria, em grande medida, uma forma de consolo a povoaçōes rurais que não dispunham de grandes expectativas quanto a sua própria existência. As relações estreitas entre a natureza, a vinculação profunda num mundo camponês, limitado por laços familiares, são ainda mais sensíveis no universo chinês do que no espaço indiano.

O Budismo exerceu influência sensível na China. Durante a Dinastia Tang (618 a 907), manifestou-se através da influência no desenvolvimento de esculturas. O chineses guardaram do Budismo, acima de tudo, o despreendimento das coisas deste mundo. Mas, com freqüência, seguiram sua própria via ${ }^{19}$.

No século VI antes de Cristo, Confúcio veio propor-lhes soluções bem distintas do Budismo. Tendo como ponto de partida, também, sua sociedade contemporânea, Confúcio chegou a solução bastante distinta daquela do Budismo. Isto porque o "momento presente" também não lhe parecia perfeito - longe disso - mas ele identificava possibilidades de transformações. Estas aconteceriam através do controle dos impulsos pessoais. Não seria necessário, como acreditam os budistas, "escapar de tudo". Pelo contrário, caberia adaptar-se.

Confúcio, assim, apresenta uma filosofia que considera o homem dentro da natureza, que se expressa pelo culto do passado, considerado como uma Era melhor, e pela comunhão com o mundo material. Daí resulta, para seus seguidores, a busca permanente da harmonia que se manifesta através do gosto por uma escrita extraordinária. A caligrafia é bela em seus menores detalhes. A

18 ZIMMER, Heinrich. Philosophies of India. Op. cit., p. 19.

19 WING-TSIT, Chan. A Source Book in Chinese Philosophy. Princeton: Princeton University Press, 1963 , p. 134. 
pintura de paisagens, como se refletissem o estado da alma, é também levada a extremos do bom gosto.

A pintura, ademais, é influenciada por um outro aspecto do pensamento chinês: o taoísmo, que é uma doutrina mais recente do que o Confucionismo. O taoísmo é uma forma de meditação sobre a ordem da natureza, muito mais mística do que o Confucionismo, na medida em que se submete à essência do mundo para poder penetrá- $-\mathrm{o}^{20}$.

Alguns pensadores concluem que a espiritualidade oriental apresenta grandezas e fraquezas, na medida em que, por um lado, é superior ao pensamento ocidental, que jamais soube dedicar a mesma humildade e busca de compreensão - a exemplo da espiritualidade oriental - às leis do mundo, aceitá-las e ir além delas ${ }^{21}$. A "simpatia universal" que, no entanto, submete o pensamento asiático à passividade, dificulta a luta das pessoas daquela parte do mundo, contra as forças da natureza, as destruiçóes provocadas por sucessivas guerras e o condicionamento de hábitos consagrados por heranças milenares.

A sociedade indiana, por exemplo, é o resultado da assimilação de centenas de influências culturais, originárias da Europa e Ásia. A Índia incorporou, portanto, costumes e crenças das diferentes civilizações que a invadiram ou lá se estabeleceram. Como resultado, hoje existem no país 17 línguas oficiais e algumas centenas de dialetos.

Mas a Índia não foi apenas "importadora" de cultura. Foi também "exportadora". O Sânscrito, como se sabe, é uma língua originária na Índia e raiz de línguas indo-européias, como o grego e o latim.

O Budismo nasceu na Índia, derivado do Hinduísmo, mas praticamente desapareceu de seu país de origem, espalhando-se pela Ásia e outras regiōes. O Hinduísmo, no entanto, foi difundido pelo Sudeste Asiático mas continuou a florescer, principalmente no território indiano.

Verifica-se, a propósito, que o Hinduísmo parece adaptar-se perfeitamente à sociedade indiana - há quem diga que, nesse caso, a religião influencia a sociedade e vice-versa. Isto é, a profusão de "deuses" oferece ampla escolha de devoção aos fiéis a teria ajudado no estabelecimento de sistema de castas que sobrevive há 3 mil anos.

\section{A abertura da China para o exterior na década de 1980}

Conforme assinalado no começo deste artigo, procura-se identificar dois momentos de ruptura - novas cenas de partida - no cenário político recente da Ásia. Nessa perspectiva, o início da década de 1980 é estabelecido como um marco, na história contemporânea da China, quando se deu o processo de abertura do país ao exterior, após o período turbulento da Revolução Cultural.

20 TUNG, Chi-ming. An Outline History of China. Hong Kong: Joint Publishing Co., 1980, p. 204.

21 GIRARD, Luis. Op. cit., p. 405. 
Naquele momento, contudo, não era possível deixar de sentir uma certa tristeza, pelo fato de que havia sido encerrada, na China, uma Era de convicção poética maoísta. A partir de 1949, acreditara-se que, em benefício do interesse comum da sociedade, centenas de milhôes de pessoas poderiam ser levadas a patamar mais elevado do que o egoísmo individual.

A experiência chinesa de busca de uma sociedade igualitária encantara a muitos. Os países do Terceiro Mundo admiravam sua combatividade e autosuficiência. Os economistas ocidentais registravam o pleno emprego atingido, no campo, e invejavam sua força de trabalho disciplinada, na indústria.

Com a maior transparência interna, decorrente do término da chamada "Revolução Cultural", ficava evidente que não se vivera na China, nas três décadas anteriores, tantos motivos de encantamento ${ }^{22}$. $\mathrm{Na}$ verdade, naquele período, perdurara o elitismo e a corrupção entre os dirigentes do partido e do governo. $\mathrm{O}$ lento progresso obtido na economia demonstrara não ser tão fácil, desenvolverse com os próprios recursos, sem a infusão de investimento, tecnologia ou ajuda externa.

Em suas relações internacionais, sabe-se, a República Popular, desde sua fundação, em 1949, havia mantido uma vasto exército e milícias armadas e desenvolvido a bomba atômica. A China tivera conflitos com a União Soviética e Índia e fricções com o Japão, com respeito às Ilhas de Senkaku, e com o Vietnã, quanto às Spratlys. Não se tratava, portanto, de país totalmente "amante da paz" - conforme os bens instruídos guias turísticos, com seus uniformes "no estilo Mao Zedong" divulgavam, em Pequim, aos visitantes estrangeiros.

No plano interno, na medida em que se conhecia melhor a real situação chinesa, ficavam diminuídos, inclusive, os ganhos considerados, por exemplo, no controle familiar. Havia sido enorme, verificava-se, o custo, em termos de direitos humanos, na proibição de casamentos antes dos 20 anos e obrigatoriedade de apenas um filho por casal.

Não se quer negar, no entanto, as grandes conquistas do período maoísta, nem os feitos do povo chinês. Um país que, na primeira metade do século XX, fora devastado por guerras internas, encontrava-se, no início da década de 1980, unificado, apesar das crises de liderança resultantes da Revolução Cultural.

Como era possível verificar, a China alimentava e vestia seu povo. Um esforço descomunal fora feito para construir represas, diques e sistemas de irrigação, bem como no sentido da auto-suficiência alimentar ${ }^{23}$. Mas seria isso suficiente? Tais conquistas teriam que ser vistas em perspectiva.

Mao Zedong tornara a "necessidade" em "virtude", como base de sustentação para política de auto-suficiência. Em grande parte, tratava-se de reação ao fato de

22 Tais observaçôes decorrem do fato de o autor ter servido na Embaixada do Brasil em Beijing, no período de 1982 a 1985.

23 FAIRBANK, John King. The Great Chinese Revolution 1800-1985. New York: Harper \& Row, 1986, p. 316. 
que os soviéticos terem cessado toda e qualquer auxílio, a partir de 1960, levando consigo, inclusive as matrizes de fábricas cuja instalação já havia sido iniciada.

O "Grande Timoneiro", então, colocou toda sua crença na "genialidade do povo chinês". Doravante, tudo seria resolvido com a mobilização permanente das "massas". Daí surgiriam energias e talentos até então escondidos por sistema social opressivo. Na década de 1960, por exemplo, ampla campanha nacional encorajava simples operários a fazerem sugestôes sobre inovações tecnológicas. Exageros evidentes eram noticiados a respeito do aumento de produtividade como resultado de soluções práticas obtidas nos canteiros de obras, campos agrícolas e operadores de máquinas nas fábricas.

O caráter "anti-científico" das práticas maoístas chegou ao apogeu durante a chamada Revolução Cultural, quando professores e alunos foram obrigados a curvar-se diante da "sabedoria" das massas. Postura semelhante foi adotada nas forças armadas chinesas, onde o conceito maoísta de "guerra popular" baseava-se na premissa de que "homens contavam mais do que máquinas". Nessa perspectiva, centenas de milhares de soldados de infantaria, com armamento obsoleto, seriam capazes de derrotar um Exército soviético equipado com armas modernas. Mantinha-se, no entanto, a dissuasão nuclear, na medida em que a China não renunciava a sua própria bomba atômica.

Com a derrota do "bando dos quatro", a China desencadeou uma outra campanha, desta feita para condenar a viúva de Mao, visando a acusá-la e a seus três cúmplices de Xangai, pela maioria dos fracassos e fraquezas do anos anteriores. Este novo processo implicou, novamente, em notáveis exageros nas acusaçóes. A mensagem, no entanto, era clara: os dirigentes chineses haviam tomado consciência de que suas políticas de auto-suficiência, recusa em aceitar ajuda externa e a negativa à aquisição de tecnologia estrangeira haviam reduzido as taxas de crescimento e o progresso em quase todos os setores da economia.

A rejeição da ideologia passada foi feita na forma de pronunciamentos que, gradativamente, desautorizassem o autoritarismo vigente na fase que se encerrava. Enquanto isso, o corpo de Mao Zedong era reverenciado no Mausoléu, em Pequim, com todas as honras devidas ao fundador da República Popular da China. Tratava-se, no entanto, de trazê-lo a proporções humanas. Começava o processo de estabelecer seu lugar na história, como um grande líder revolucionário, mas como um homem com menor sucesso, quando se tratou de administrar um país. Suas principais preocupaçōes diziam respeito à eliminação dos dogmas socialistas, agora vistos como impedimento à nova marcha da China, em direção à modernização. O principal responsável pelas alterações na condução das políticas, econômica e social da China, a partir de 1978, e "Novo Timoneiro", passou a ser o então Vice-Primeiro-Ministro Deng Xiao-Ping.

O julgamento público de Mao, no entanto, tinha dimensóes restritas. Todos os erros cometidos no período de radicalização maoísta eram atribuídos a Lin Piao e ao "bando dos quatro". Para o cidadão chinês, contudo, havia implicações 
óbvias: não era possível aceitar que toda a culpa fosse atribuída a um traidor e a quatro radicais - na prática, os atuais dirigentes em Pequim estavam admitindo que a "Grande Revolução Proletária Cultural" havia sido um fracasso enorme e custoso.

O próprio retorno de Deng Xiao-Ping ao poder, como Vice-Primeiro Ministro já significava uma rejeição eloqüente do julgamento de Mao, que havia dado seu apoio pessoal às duas quedas anteriores de Deng ${ }^{24}$.

Não era possível ignorar, contudo, que Mao tinha razão quanto ao diagnóstico sobre os males que atingiam a China. Assim, de acordo com sua visão, o maior perigo para o país seria o retorno à estagnação imposta pela burocracia do partido e do estado. Suas soluções eram poéticas e imaginativas: uma série de campanhas para mobilizar os intelectuais - "O Movimento de Cem Flores" - a busca de um caminho mais curto para o Socialismo - "O Grande Salto Adiante" - e a provocação de uma "discórdia criativa" entre a juventude do país e a burocracia estatal - "A Revolução Cultural". Mas, como se sabe, Mao não obteve sucesso na criação do "homem socialista". Ele pediu demais, tanto dos chineses, quanto da natureza humana.

No final da década de 1970, no entanto, todo este processo havia sido esquecido. Ficara provado que, em tese, era uma boa idéia encorajar os trabalhadores a pensarem o aumento da produção com seus próprios meios. $\mathrm{Na}$ prática, a premissa ideológica, sobre a qual se baseava - a de que a sabedoria está consagrada nos trabalhadores - conduziu a medidas impraticáveis, como por exemplo, a utilização de máquinas antiquadas sendo utilizadas em velocidade inapropirada, provocando acidentes ou resultados negativos. Verificava-se, por exemplo, que a produção de cereais ficara estagnada. Não houve progresso em projetos de irrigação, nem de novos fertilizantes agrícolas, enquanto a população chinesa continuava a aumentar. O país continuou a importar alimentos.

A mesma ausência de melhoria foi notada no setor industrial, onde prevaleceu a política maoísta de auto-suficiência e oposição a aprender da experiência de outros países. Tal postura levou, por exemplo, à estagnação da produção anual de aço, ao lento progresso tecnológico, a preservação de fábricas antiquadas, com equipamentos, tecnologia e formas de administração superados e emprego excessivo de mão-de-obra.

Com a morte de Mao Zedong e a derrubada do "Bando dos Quatro", a China poderia, finalmente, defrontar-se com estes fatos negativos e tomar as decisões cabíveis, para superá-los. Havia sido abandonado, no entanto, o fundamento da filosofia maoísta: o "conceito hegeliano" de que a unidade deve ser dividida em duas partes e que cada situação contém em si contradições saudáveis que são necessárias para a luta e o progresso, levando, assim, à noção de luta de classes contínua e revolução permanente ${ }^{25}$.

24 CHI Hsin. Teng Hsiao-Ping a political biography. Hong Kong : Hong Kong Printing Works, 1978, p. 50.

25 LEW, Roland. Mao prend le Pouvoir. Bruxelles: Éditions Complexe, 1981, p. 145. 
Segundo Mao, a China não deveria jamais permitir-se cair na complacência da "unidade" e, de acordo com esta filosofia, o "Grande Timoneiro" teve a audácia poética de desencadear uma revolução contra seu próprio governo e partido. O veredicto da história será provavelmente o de que, enquanto Mao foi uma dos maiores líderes revolucionários, demonstrou ser um governante menos habilidoso, uma vez que sua revolução tornou-se vencedora. Provocou, assim, severas perdas a seu país, enquanto perseguia suas visões utópicas.

No início da década de 1980, portanto, o sentimento dominante era o de que a morte havia "humanizado" Mao Zedong e "desmistificado" a China, que, então, admitia suas limitações no trato com os grandes problemas do país. Naquele momento, poucas pessoas continuariam a expressar uma opinião própria sobre o que a China deveria ser, em oposição ao que a China passava a dizer o que realmente era. No plano internacional, poucos países em desenvolvimento continuariam, a partir de então, a considerar a experiência chinesa, desde a fundação da RPC, como um modelo a ser seguido.

A nova política pragmática representava praticamente a recusa total das doutrinas que haviam dominado as políticas agrícola e industrial dos últimos 20 anos. Todas as empresas públicas, por exemplo, foram instruídas a gerar lucros proposta impensável, até recentemente. Incentivos materiais passaram a substituir a pureza ideológica. A China se conscientizou de que necessitava da tecnologia do Ocidente e, enquanto abandonava sua política restritiva de "auto-suficiência", começava a buscar fontes de financiamento de longo prazo - ajuda, em outras palavras - para financiar suas compras de know how, instalações industriais, navios, equipamento de transporte e material de emprego militar ${ }^{26}$.

A emergência econômica chinesa é, hoje, fato incontestável e objeto de noticiário cotidiano pela imprensa mundial. Permanecem, contudo, incertezas críticas, sobre um cenário futuro favorável ou pacífico da China ${ }^{27}$. Entre estas, a dúvida sobre se aquele país será capaz de manter o controle sobre a evolução de sua política interna e economia. Isto porque, existe pressão crescente do hiato entre ricos e pobres, da poluição sobre as grandes cidades em função da industrialização sem controle, de um sistema bancário contaminado por empréstimos impagáveis, pelo confronto entre uma economia quase de mercado e um regime político altamente controlador.

Até o momento, as autoridades governamentais demonstraram competência para administrar estes problemas. As Olimpíadas de 2008 e a Exposição de Xangai, em 2010, representam poderosos incentivos para a manutenção da estabilidade. Assim, o sistema unipartidário deverá ser preservado, a todo custo, como forma de exibir uma China estável, perante o resto do mundo.

26 KRISTOF, Nicholas D. \& WUDUNN, Sheryl. China Wakes - The Struggle for the Soul of a Rising Power. London: Vintage, 1995, p. 338-366.

27 BERSTEIN, Richard \& MUNRO Ross H. The Coming Conflict with China. New York: Alfred A. Knopf, 1997, p. 2-21. 


\section{A atual emergência da Índia}

O processo atual de ruptura indiana com seu passado de estagnação econômica é o segundo momento, conforme anunciado na introdução do artigo, a representar uma verdadeira nova cena de partida na história recente do continente asiático. Este desenvolvimento deve ser entendido na perspectiva histórica, ou seja, do passado colonial do país, sob o domínio britânico, que deixou o legado da associação da abertura ao exterior com a exploração estrangeira.

Assim, Jawaharlal Nehru, o primeiro líder da Índia, pós-independência, em 1947, voltou-se para a União Soviética, como um modelo para processo de transformação de uma sociedade atrasada num "mamute" industrializado. O planejamento central, então, seria a chave para o progresso. Todos os mecanismos de controle da economia indiana foram nacionalizados. Tais medidas fortaleceram três grandes grupos de interesse, então determinados a assegurar que a Índia fosse mantida nesse caminho. Estes eram constituídos por uma burocracia de vinte milhões de pessoas; um partido político, o Congresso ${ }^{28}$; e uma comunidade empresarial interessada em crescer sob a proteção de barreiras comerciais entre as mais elevadas do mundo.

Nessa perspectiva, durante os trinta anos seguintes, a Índia perseguiu uma política de "auto-suficiência", de forma a que a indústria local veio a produzir praticamente tudo - aço, máquinas e ferramentas, carros, locomotivas, bens de consumo elétricos e eletrônicos duráveis, produtos para uso industrial, têxteis, calçados, papel, produtos farmacêuticos, computadores e mesmos usinas nucleares e satélites de comunicação. Esta diversidade parecia impressionante mas, na verdade, as indústrias em questão eram, com freqüência, ineficientes. Além disso, eram prejudicadas por legislações burocráticas que dificultavam a instalação de novas empresas.

No final de década de 1970, portanto, ficou claro que mudanças eram necessárias. A maioria dos produtos indianos não podia competir internacionalmente, as exportações não haviam decolado, enquanto as importações aumentavam, levando a déficit comercial crescente. Enquanto isso, tornava-se cada vez mais aparente que o peso colocado sobre o setor público era excessivo e que as perdas decorrentes contribuíam para a drenagem de recursos nacionais

A partir do início dos anos 1980, a Índia juntou-se à China como mais um país emergente na Ásia e vem apresentando algumas características marcantes que despertam crescente atenção dos analistas internacionais, como taxas elevadas e sustentáveis de crescimento econômico, da renda real per capita e das exportações de bens e serviços. $\mathrm{O}$ setor de serviços, em particular, não apenas tem sido o motor dinâmico do crescimento indiano desde o início dos anos 1990, como

28 KEAY, John. Op. cit., p. 527, apresenta cronologia da participação dos partidos políticos indianos no Governo indiano, a partir de 1947. 
também constitui um dos principais itens da pauta de exportaçōes do país, com destaque para os serviços de tecnologia da informação (notadamente softwares).

Embora quase todos os indicadores de desenvolvimento para o início do milênio retratem aparentemente problemas ainda mais graves que o Brasil, os quais levarão décadas para serem superados, a situação melhorou relativamente à que prevalecia até o final da década de 1970 . A parcela da população vivendo abaixo da linha de pobreza reduziu-se de 55\% em 1974 para 26\% em 2000. Como no início dos anos 1990, esse percentual era de cerca de 34\%, é lícito atribuir ao processo de crescimento econômico dos últimos 14 anos essa melhora de bem-estar.

Mesmo com mais de 300 milhões de pobres, a Índia conta com dois trunfos que, mantidas nas próximas décadas as elevadas taxas de crescimento, aumentariam as chances de melhorar consideravelmente o nível geral de bem-estar social: primeiro, detém um tradicional regime democrático parlamentarista, bem como instituiçôes governamentais e privadas relativamente modernas e consolidadas; segundo, ainda que o número absoluto de pobres seja bastante elevado diante do tamanho de sua população (cerca de $31 \%$ do total), o padrão de distribuição de renda é bastante eqüitativo comparado ao normalmente evidenciado em diversos países em desenvolvimento.

Nessa perspectiva, mantido o ritmo de crescimento econômico e de aumento da produtividade das últimas duas décadas, as possibilidades de melhorar as condições gerais de vida da população, sem o risco de conflito entre as classes sociais são politicamente muito maiores, tendo em conta o padrão razoável de distribuição da renda nacional ${ }^{29}$.

Segundo publicação do BNDES, em janeiro de $2006^{30}$,

"Diferentemente da experiência latino-americana (especialmente a brasileira), a origem do modelo indiano de substituição de importaçôes não está relacionada a crises crônicas do balanço de pagamentos. Da mesma forma, os processos de planejamento econômico e as políticas protecionistas em prol da industrialização indiana, antes que amparados por argumentos como a perpetuação das restriçôes externas devida à dependência de exportação de produtos de baixa elasticidade-renda da demanda, como foi também o caso dos países "grandes" da América Latina (e do Brasil, em particular), foram fortemente influenciados pelo modelo de economia "fechada" da antiga União Soviética.

Para esse fim, a exemplo da maioria dos países de industrialização retardatária (late comers), a Índia se valeu de políticas domésticas e comerciais externas protecionistas, mas, no caso indiano em particular, tais mecanismos foram

29 AYOOB, Mohammed. India and Southeast Asia: India Perceptions and Policies. New York: Routledge, 1990 , p. 25.

30 NASSIF, André. A Economia Indiana no Período 1950-2004 - da Estagnação ao Crescimento Acelarado: Liçōes para o Brasil?, Textos para Discussão 107. Brasília: BNDES, 2004. 
aplicados de forma tão exagerada que, em meados da década de 1970, a economia operava sobre bases praticamente autárquicas. Em meados da década de 1980, a ineficiência microeconômica, o nível de degradação social, a debilidade do sistema de infra-estrutura e os mecanismos precários de inserção internacional, sobretudo pela via das transaçôes comerciais, deixavam cada vez mais claro que o modelo de desenvolvimento econômico indiano, com características praticamente autárquicas e grau bastante elevado de intervenção do Estado, não seria sustentável no longo prazo.

\section{Conclusão}

Conforme mencionado no início deste artigo, China e Índia ocupam, hoje, espaços quase idênticos nas atenções mundiais. Vive-se, agora, no subcontinente indiano momento semelhante - guardadas as diferenças geográficas e culturais que se procurou expor no artigo - ao vivido, por exemplo, após a excursão de Deng Xiaping ao Sul de seu país, em 1993, quando declarou que "ser socialista é ser rico".

Isto é, prevalece, na Índia, clima de expectativas crescentes de que todos os obstáculos serão superados, em benefício de um crescimento econômico sustentável exponencial. A diferença fundamental, no entanto, é o fato de que, na Índia, o processo ocorre a partir da determinação da sociedade civil. Dependerá, portanto, de apoio popular e de diferentes setores da economia, para superar definitivamente os pontos de estrangulamento criados às forças de mercado, pelos mecanismos herdados de um planejamento centralizado.

A importância maior da atual emergência da China e da Índia, encontrase, no entanto, na análise de como estas culturas evoluíram e se adaptaram aos sucessivos desafios históricos que lhe foram impostos. Que tipo de influência estas alterações terão no cenário internacional? A China tem reiterado que sua condição atual de potência emergente deve ser entendida como uma nova fase histórica, marcada por "ascensão pacífica" do país, destinada a beneficiar seu entorno imediato e relações com o exterior. Nesse contexto, cabe examinar o crescente compromisso de Pequim com as naçóes ao Sul de suas fronteiras, que representariam o agrupamento regional onde aconteceria, prioritariamente, esta "ascensão chinesa".

Quanto ao fenômeno indiano, cabe avaliar se existe, realmente, processo sustentável de crescimento ou se não se trata, por um lado, de exercício promocional do Governo de Nova Delhi, com sua campanha de divulgação de "India everywhere", ou, por outro, de contra-ofensiva de empresas multinacionais assustadas com sua excessiva dependência da economia chinesa e, portanto, interessadas em criar alternativa para seus investimentos ${ }^{31}$.

31 A revista britânica The Economist de 3 de junho de 2006 publica editorial com o título Can India Fly e suplemento intitulado Now for the hard part - A survey of business in India, nos quais é traçado um cenário futuro favorável para a economia indiana. 
Ao contrário dos chineses - como se procurou demonstrar nas segunda e terceira partes do artigo - os indianos nunca procuraram expandir sua cultura, nem suas instituiçōes democráticas. Sua grande preocupação parece ser a garantia da segurança interna de sua multiculturalidade, em ambiente internacional estável. A liderança atual indiana, portanto, parece entender que a inquietação mundial, provocada por rivalidades étnicas e religiosas, poderá afetar, também, seu próprio país. Daí, Nova Delhi ter que exercer amplo leque de interlocução com culturas que rodeiam a Índia.

$\mathrm{Na}$ medida em que se consolide a emergência destes dois países, que possuem laços de vizinhança milenares, bem como se desenvolvam cooperação mais intensa e troca de ensinamentos sobre como administrar seus respectivos processos de crescimento exponenciais, haverá, sem dúvida, impacto significativo no ordenamento político internacional.

Basta lembrar que, há pouco mais de 50 anos, foram ambos os promotores dos chamados Cinco Princípios de Convivência Pacífica. Caberia, agora, desejar que contribuam para um relacionamento internacional baseado no respeito mútuo entre culturas diversas.

Recebido em 14 de janeiro de 2007 Aprovado em 9 de março de 2007

\section{Resumo}

China e Índia fazem parte do noticiário cotidiano. Dois momentos históricos recentes marcaram aqueles países. O primeiro foi a abertura chinesa para o exterior, na década de 1980. O segundo é a emergência indiana atual. A maioria das análises disponíveis, no entanto, se esgota na expansão das duas economias. O artigo, contudo, busca situar o impacto que a multiculturalidade daquelas civilizações poderá causar em novo ordenamento internacional, distinto do atual, onde prevalece a força militar e o poder econômico. São apresentadas, em linhas gerais, as origens e a espiritualidade dos povos em questão.

\section{Abstract}

China and India are constantly acknowledged in the daily news. Two recent events can be seen as historical benchmarks for those two countries. The first was the opening of China to the outside world, during the decade of the 1980s and the second is the current rise of India. In most of the analysis available today, the focus is on their growing economies. This article seeks to address a different approach, aiming to evaluate what impact their multicultural population could have in a new international order, which, in opposition to what now prevails, would not be based on military strength or economic power. In broader guidelines, the origins and spirituality of those two people will be discussed.

Palavras-chave: China, Índia, Emergência cultural.

Key words: China, Índia, Cultural rise. 